\title{
Urban Utopia and Building Experimentations: The Rural Villages of the Sicilian Latifundium
}

\author{
Vincenzo Sapienza \\ Department of Civil Engineering and Architecture, Catania University, Catania 95125, Italy
}

\begin{abstract}
The colonization of Sicilian latifundium was an attempt of regeneration of the rural areas. It was carried out by Benito Mussolini, called Il Duce, who governed Italy by a regime with an absolute and conservative approach for 20 years since 1922. According to this plan, there were some rural villages (with a school, a church, a police station and a doctor's surgery) and a number of rural homes, spread in the landscape, that formed one of the most important achievements of the agrarian reform in Italy. The author has been conducting scientific research on this topic for several years. He started with the archive "Ente per la Colonizzazione del Latifondo Siciliano" (now called Ente Sviluppo Agricolo) to review the original designs and contracts with companies, ledgers and other administrative documents. Lately, he has been reviewing the personal archives of designers involved in the building program, where he has found original drawings, letters, sketches, etc.. He has also conducted some architectonic and technical surveys of the sites. We have to consider that nowadays the mentioned rural villages are a strategic resource for the development of the neighboring areas, as it may become a network for the sustainable tourism and the promotion of the local agro food specialties. On this purpose, the local authority is going to promote some plans for the requalification of these sites. The particular achievement of this article is to show a number of possibilities for the reuse of these places.
\end{abstract}

Key words: Rural village, autarchy, construction history, rehabilitation.

\section{Introduction}

One of the most important social topic of the 1920s and 1930s in Italy, as in more European nations, is related to the distribution of the land to the farmers. In fact, during the World War I, the soldiers resisted bravely in the trenches on the Carso mountains and defended the Piave's line thanks to the government's promise to have an agricultural reform.

At the end of the war, Italy was suspended between the authoritarian regime and the communist revolution (the minaccia rossa). The first option prevailed in the 1922, when Benito Mussolini, Il Duce, was declared first minister.

In fact, owing to the poor origins of his family and his membership to the socialist party's ranks as a youth, his approach in national politics was based on a strong

Corresponding author: Vincenzo Sapienza, assistant professor, research fields: history of construction, building construction and building sustainability. E-mail: vincenzo.sapienza@darc.unict.it. support of the farmers' class. So he carried out numerous attempts to regenerate rural areas in many regions of Italy such as Emilia Romagna, Latium, Apulia and Sardinia [1]. In this framework, you can insert the expansion in the African colonies, as Libya, Ethiopia and Somalia [2]. In addition to the social goals, there was the pragmatic approach to increase cereal production.

In Sicily, the intervention measures were carried out at the end of 1930s, with the start of the Colonization of Sicilian Latifundium Program: a blend of economic and social standards designed with the purpose to fight the latifundium setting of internal and rural areas [3].

If you consider the origin of Sicilian latifundium in only a few words, you have to go back to the Roman age, when Sicily was a province of the empire. At that time, they formed really big estates, the latifundium. Their constancy was preserved by the successive centuries because it was related to the profits of the ruling class, the nobles. Nevertheless, during the 20th 
century, the meaning of the term "latifundium" was no longer related exclusively to the extension of the area. The latifundium's areas were characterized by two specific factors: extensive farming and gabella tenancy, a form of tenancy, very diffuse in the arable areas of southern Italy, which was particularly oppressive. So you had under utilization of the production capacity of the land and super-utilization of human labor. There you had large semi-desert land holdings, without houses or trees "where the man gives shade to himself" [4].

In the opinion of the economists of that age, this type of organization has been the principal reason for the economic and social underdevelopment of Sicily.

The colonization that was attempted during the fascist era, which will be treated in the prosecution of the article, was only a short but really significant part of the very long and tormented agrarian reform in Sicily. In fact, it was the era where the most important events of recent history, such as the Illuminist vice-regency of the marquis Domenico Caracciolo, or the rising of Fasci Siciliani, or the proposal of Francesco Crispi and many other events [5] took place. In the post-war era, the events have had a further continuation with the push of Autonomist Movement.

\section{The Sicilian Latifundium Colonization}

Although Mussolini fought strongly for the large conurbations, he built nearly 150 villages and cities, in various regions of Italy [1]. Generally, the settlements followed land reclamation. The best known example was developed in Agro Pontino, but his plan for Sicily was one of the most interesting and innovative.

The Sicilian latifundium colonization was based on the "rural city" of Edward Caracciolo (the father of local town planning). The unit of his plan has been formed by the colonial house with the farm attached to it. They have spread in the country and have been related to a network of rural villages, of different dimension, where they could find the basic social services (school, church, police station, the doctor's surgery, etc.). The distribution of the buildings has been based on the size of the farm, related to the sustenance of an average family. The rural villages have been situated on the nodes of a squared mesh, formed by the division of the land. The design has been studied to balance the number of public buildings with the consumers, considering the compatibility with the pedestrian distance [6]. The basic motivations have been very easy and pragmatic: The farmer spent a large part of his day's work in the walk from his home, in the little town, to the work place, in the countryside. Moreover, he could not take advantage of the assistance of his wife and of the sons that remained at home. From this argument, it was necessary to locate the farmer's house in the land (Fig. 1).

The theme of the design of the new cities is very recurrent in the modern architecture history. In particular, both fathers of modern movement, Le Corbusier and Frank Lloyd Wright, have defined a plan similar to the Caracciolo's one. In fact, Les Trois Ètablissements Humains and Broadacre City are an attempt to solve the contraposition between city and country, industry and agriculture, conurbation and landscape, exactly as the Sicilian rural city.

The program of colonization was realized when law entitled "The Colonization of Sicilian Latifundium" (n 1 of $2 / 1 / 1940$ ) was approved by the Italian parliament. According to this law, the owners of the estates were obliged to arrange the division of their lands, to build colonial homes and to rent some of the lands with contracts of 10 years. To support the residential plot, assigned to the private initiative, the government pledged itself to build the rural villages, that were divided in three categories in accordance to the type of the building and cost [7].

With the same law, the Agency Sicilian Latifundium Colonization (in Italian language the "Ente per la Colonizzazione del Latifondo Siciliano" or ECLS) was founded to supervise and plan the territorial transformation. This agency drew up a three-year program to build 53 rural villages (23 large and 30 small ones) and 20,000 colonial houses. During the 


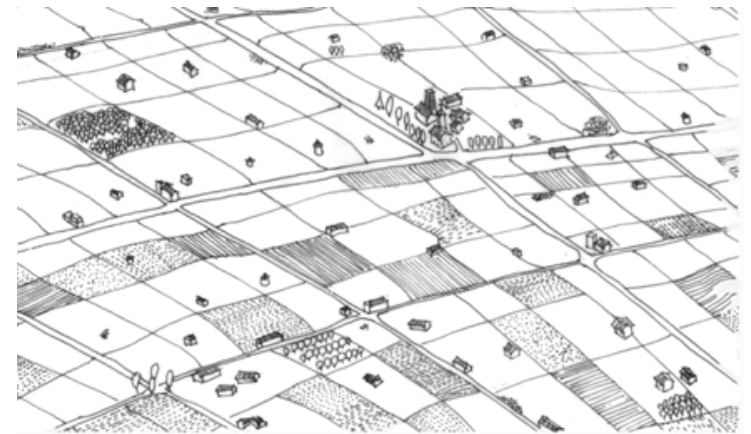

(a)

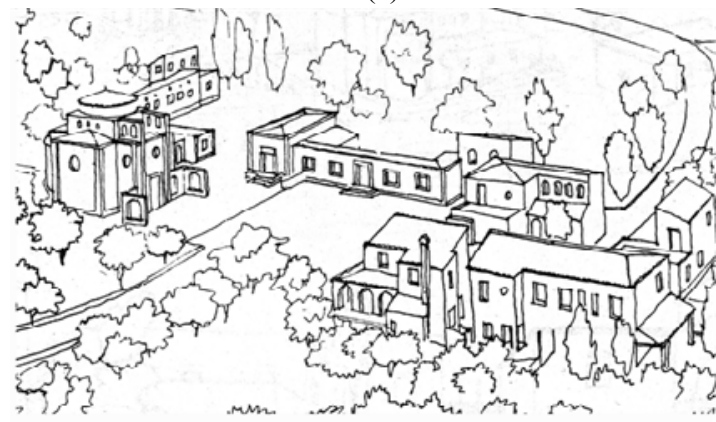

(c)

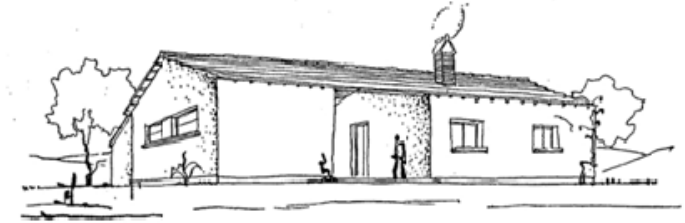

(b)

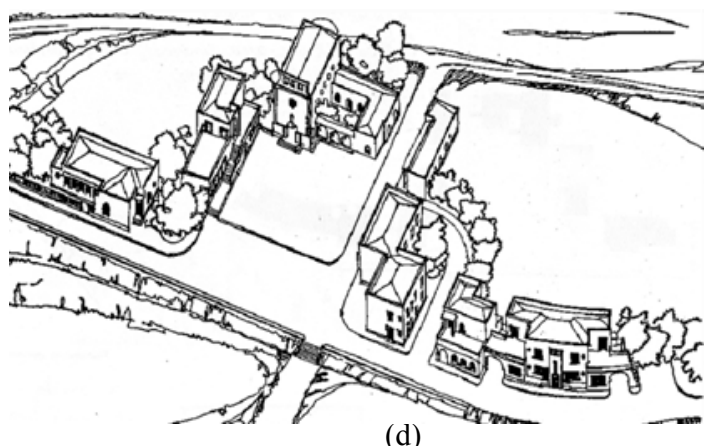

(d)

Fig. 1 (a) The rural city of Eduardo Caracciolo; (b) the rural village, Borgo Ferrara, near Palermo; (c) the design of the colonic house; (d) the rural village, Borgo Fazio, near Trapani.

first year of activity, eight villages were built and more than 2,000 houses spread in rural Sicily. The start of the building works, from October 20, 1939 to December 18,1940 , were praised by the national press, as part of the propaganda campaign that was used by the regime to contrive the meeting of the minds. In 1941, they started to build another seven rural villages. Then the agency activity was interrupted by the war [8].

The rural villages are the most prominent component of the rural city designed by Edoardo Caracciolo. The fascist regime engaged the intelligenzia of the island for the design of the works: Giuseppe Marletta, Francesco Fichera and Luigi Epifanio (to name only the most famous ones) represented the perfect mix between the erudite and designer, the architect and the town-planner, the traditionalist and rationalist [9]. For this reason, many buildings have points of interest for urban setting, architectural image and construction technologies, as it is shown in the topical literature $[1,4$, 6-8].

\section{The Urban and Architectural Setting}

The architectonic language of the buildings is the result of a mediation between the opposite trends that are found in Italy and in all Europe at that time: the simplification of lines and volumes, from Deutsche Neue Sachlichkeit, and emphasis and monumentalization, from new tradition. The first was the initial core of the modern movement, while the new tradition, showed from Giedion [10] in Italy, was called "Littorio Style" and it was typical of the public buildings as you can see at Via dei Fori Imperiali or in the area of the Universal Exposition of 1942 (known as E42), both in Rome. For the particularity of the Sicilian theme, you have to add other trends: the stoicism and the vernacular language. All these themes, softly mixed, are found in the buildings of Sicilian rural villages (Fig. 2).

As it is well known, Italy in this period was autarchic. In fact, for the expansionist war against Ethiopia, the League of Nations had assigned to her strong censure. Then the economic embargo had brought a scarcity of 
Then the economic embargo had brought a scarcity of imported goods and in particular steel for building. So the necessity to renounce structural steel works and the parsimony of use of reinforced concrete reduced the expressive power of the designers commissioned by the administrative authority. They had to eliminate the projecting features and use wooden pent roofs instead of the flat ones and, for the porticos, the masonry arches instead of the pillar-beam system.

A central role is carried out from the square, in which you have the facades of the principal buildings. The square is a protagonist in the urban planning of all Sicilian cities, in large as well as in the small ones. The interpretation of the theme is different for each rural village, it depends on the intentions of the designer that whether they have a regular and closed space or simulate the disorder and asymmetric disposition of the nature.

\section{Technology Setting}

It is possible to divide the buildings of Sicilian rural villages in two categories: special buildings and ordinary ones [9].

The first group is primarily comprised of churches. They present a single nave, but some of them have lateral chapels. They are covered by a gable roof. The bell tower is isolated. It is a very different model from the church at Borgo Petilia that has a central plan.

The ordinary buildings are the rest of them. Obviously, they are the larger group. They have one or two levels and they are organized with the rooms situated along two lines, served by small lobbies. Frequently, they have a porticos on the side along the road or the square. Sometimes, they have a terrace for a roof (Fig. 3).

Regarding the building materials, the vertical structures are exclusively masonry. You have a large variety of masonry types, depending on the different areas of the isle. In each village, you can find the use of local stone with the related texture, according to the shape and dimensions of the material (Fig. 4).

The floors are in general precast, the more common used type is without provisional reinforcement (it was indicated with the abbreviation SAP (Senza Armatura Provvisoria)). SAP is a patent of a historic Italian pre-cast factory, called RDB (Rizzi, Donelli, Breviglieri) by the surname of the first owners. The beams are the tile-lintels, modeled with slots suitable to fix the steel rods. The tile-lintels have been designed to be collaborative to minimize the metal reinforcement. Moreover, you have the advantage of the more rapid work executions and of the lack of provisional structures.

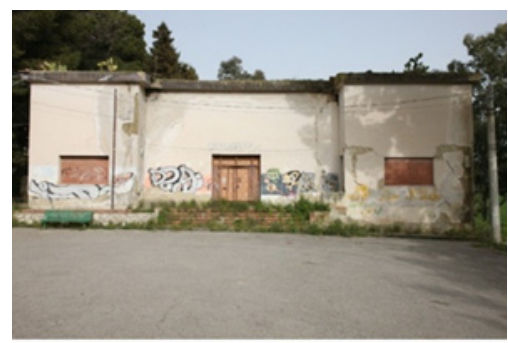

(a)

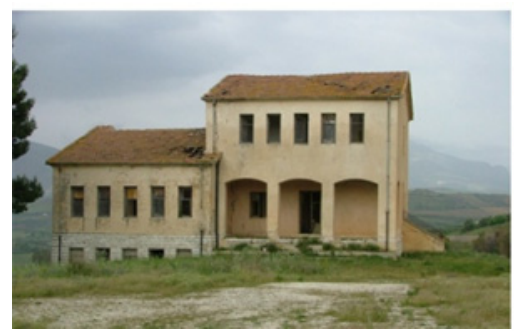

(d)

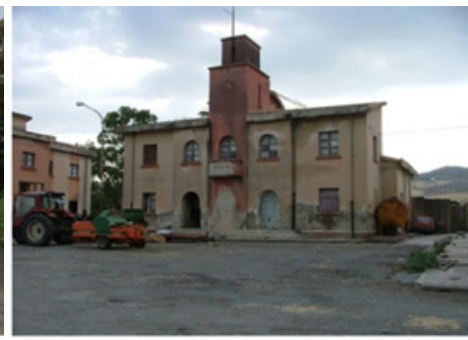

(b)

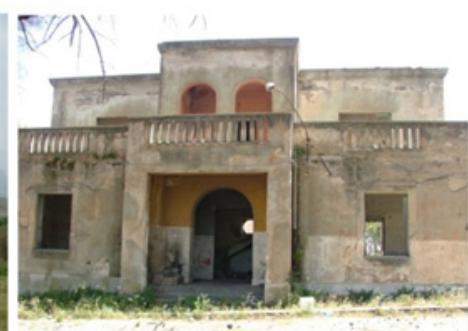

(e)

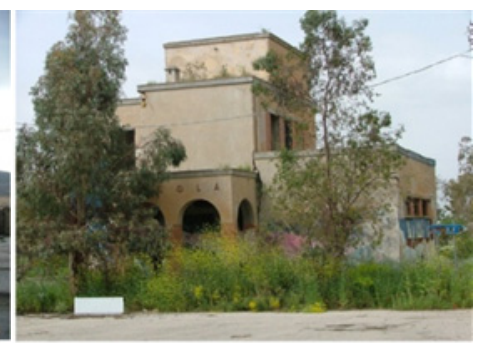

(c)

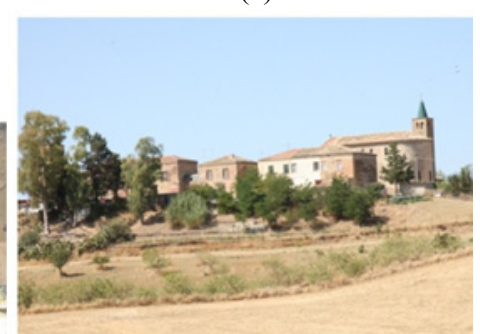

(f)

Fig. 2 Some rural villages of Sicilian latifundium: (a) Borgo Petilia (Caltanissetta); (b) Borgo Lupo (Catania); (c) Borgo Schirò (Palermo); (d) Borgo Borzellino (Palermo); (e) Borgo Rizza (Catania); (f) Borgo Cascino (Enna). 


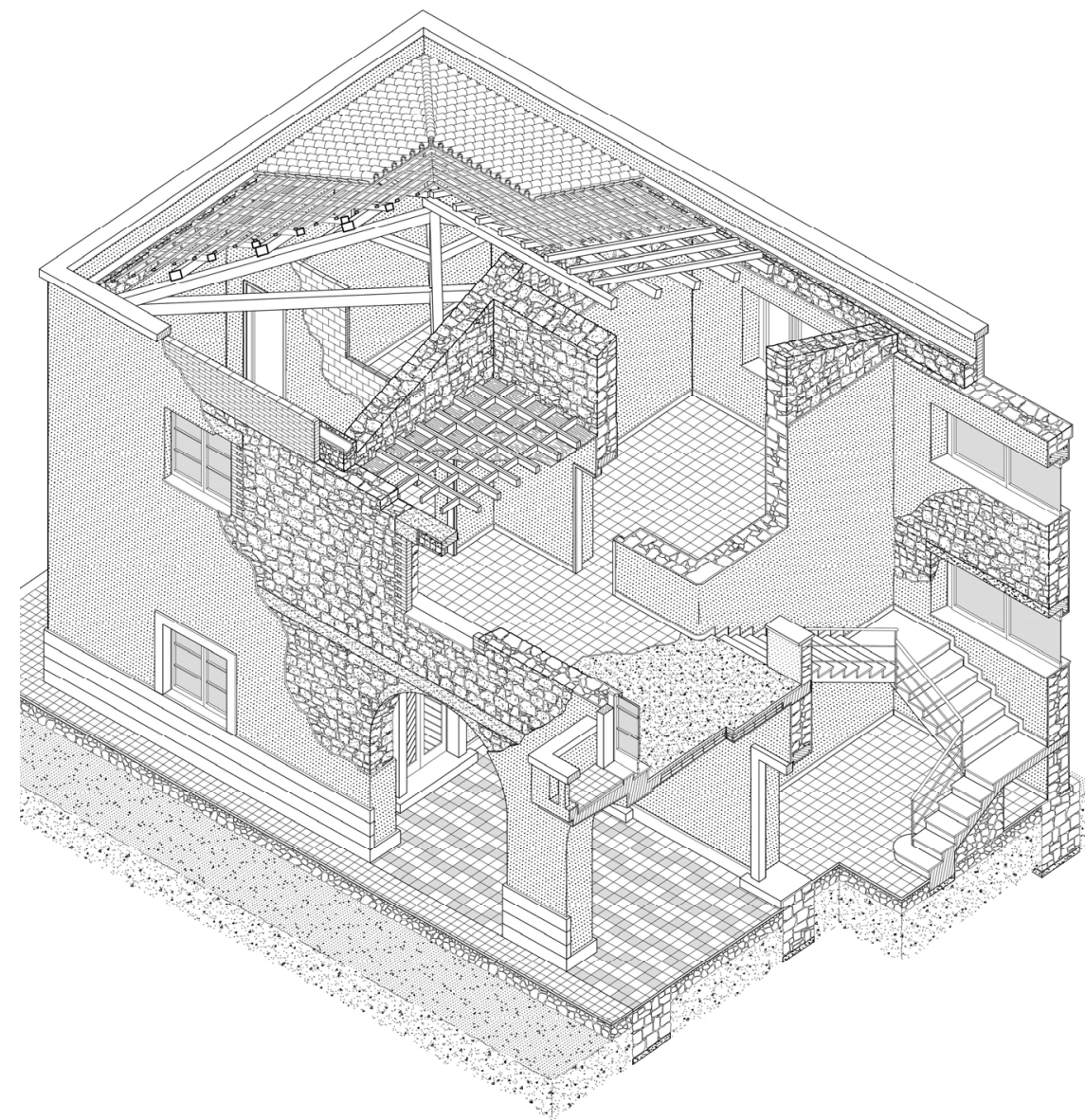

(a)

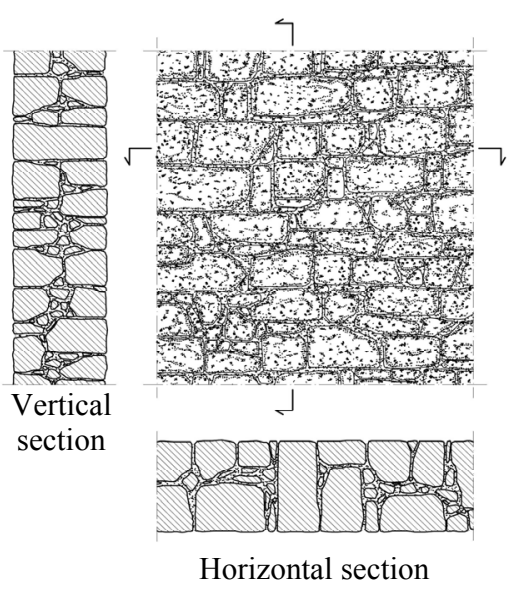

(b)

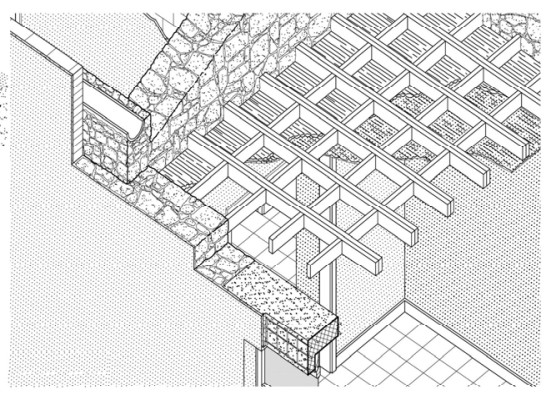

(c)

Fig. 3 (a) Construction survey of Casa del Fascio of Borgo Giuliano (Messina): cutaway isometric; (b) masonry type; (c) detail of the roof.

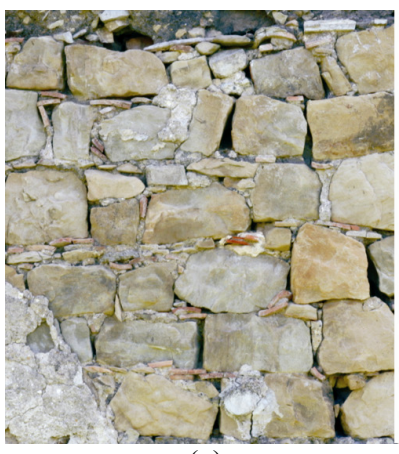

(a)

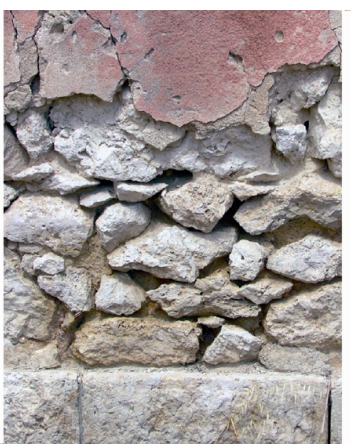

(b)

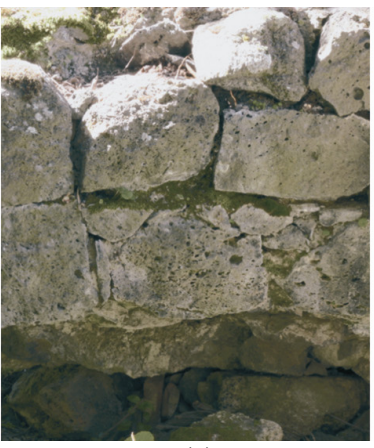

(c)

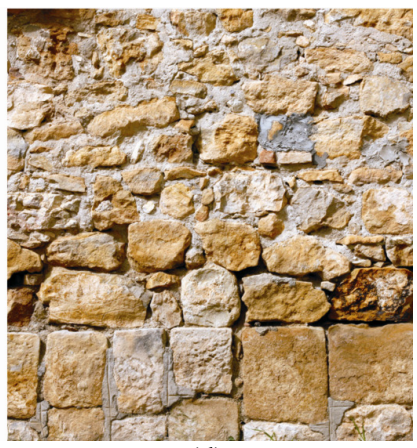

(d)

Fig. 4 Different types of masonry: (a) Borgo Giuliano (Messina); (b) Borgo Guttadauro (Agrigento); (c) Borgo Caracciolo (Catania); (d) Borgo Cascino (Enna).

The roofs in large numbers are constructed from wood with two pitched roofs, covered with plain tiles (Marseillais), more expensive than the traditional ones (tiles and canals).

Plaster is the most common type of finishing facades: the prevalent colors are yellow ochre and brick red in keeping with the shades of the surrounding landscape.

There are a few different buildings, for example, the churches which have a structure formed by reinforced-concrete portals (usually five), the walls that keep a little static role, are stone masonry, also for the considerable height. 


\section{The Abandonment of the Villages of Sicilian Latifundium}

Unfortunately, the rural city was an immediate failure, some villages and many colonial houses had not even started to work. The reasons for this were various. It is certain that the principal reason was the World War II, in fact, attention and resources were destined to something else rather than to the regeneration program. So it is not possible to make a global judgment on the colonization, considering that it was not completed but possible to weigh some aspects.

In particular, it is plain that the settlement model had some limitations that prejudiced the possibility of success. In fact, Sicilians preferred to live in the city rather than in the countryside for secular traditions. Other problems had been the restricted budget, the limited cubing of the colonial homes, the delay of creating infrastructure and the insufficiency of the staff of the rural villages.

\section{The Conservation}

The deplorable conditions of the villages in the Sicilian latifundium are a result of several causes. Two are the most important: the choice of inadequate locations and the absence of maintenance.

The urgency to show a concrete result, useful for the propaganda, led to the building on sites which had a high water table. Moreover, the characteristics of the soil were made worse by the lack of sewage network that contaminated and further waterlogged the ground [11].

But the more serious cause and what directly related to the damage of buildings were the absence of maintenance. Until the 1960s, the agency had attended to them frequently to rebuild, almost completely, the more damaged buildings [3]. Sometimes, the works have been connected to the enlargement of the villages or to conform to new uses. After this time, these places have been left completely neglected. The deterioration of the facade has exposed the building elements to a fast impairment that, not adequately impeded, has led to partial collapses. Small damage, not immediately addressed, has led to drastic consequences.

The fundamental role of the abandonment in the deterioration of the buildings is confirmed by this fact: at the moment a few rural villages are working (because illegally occupied [3], or partially utilized) and their conservation is largely better than others. So the rehabilitation of the finishings, in a large numbers of cases, is enough to solve the bad conservation. The works might take advantage by the linear simplicity of the architectures, not any particular type of protection.

\section{Conclusions}

The villages of Sicilian latifundium represent a very important resource from different points of view: historical, cultural and environmental, and it should not be squandered.

The historical aspect is very strong. In spite of disadvantages highlighted, it must be said that the villages still retain the architectural and constructive features of their period in the non-urban version. The failure of the rural city preserved the rural villages in their original status: in fact, the changes, according to their possible different use, have been very limited.

Furthermore, their historical and documental value is very high, if you consider that these buildings are a concrete symbol of considerable part of the modern history of the island: an intricate mix of class struggle, social utopias and political actions, known as "agricultural reform", that joins the southern Italy to many other parts of the world.

Finally, they represent a very important environmental resource. In fact, a large percentage of them are situated in strategic areas, i.e., areas of low density housing, without surrounding development. The latifundium has survived, still now, around the rural villages. But nowadays, it makes for a charming landscape. In the past, a place without infrastructures was synonymous with hard work, desolation, difficult communication, malaria and other illnesses. In the present age, it appears as a peaceful place, where you are able to discover a direct link with nature. 
So there are many opportunities, regarding the possibility or reuse of them [9].

First of all, it could be considered the spread of the knowledge of the agro food specialties of each specific place. In Sicily, as you probably know, there are a large variety of fruits, cheeses, meats, fish and an amazing number of ways to cook them. This is a richness that must be evaluated more and more. Nowadays, as you know, the quality of the food is highly appreciated thanks to the slow-food restaurants. More than this, there is a considerable growth of the knowledge that it is better to choose low carbon footprint products ("chilometro Zero" in Italian language). So the rural villages could become successful as market places of the local special foods.

Certainly, the rural villages could have an important role as an attraction for tourists, especially if you consider that there are new high sustainability tourist packages. In fact, there is an increasing number of tourists who prefer to visit countries on foot or riding or cycling. The rural villages could be the perfect location to have a stop because they are not very far from each other.

Also, the rehabilitation of the rural villages of the Sicilian latifundium could have a cultural goal: the isolation, the tranquility, the link with the surrounding nature, etc. are highly suitable for ateliers for visual arts, holiday schools, research laboratories and so on.

These are only some ideas to which you can add many more, such as location for extreme sports, cultural farms, for alternative forms of incarceration such as working on license outside prison, etc.. The best way to follow, probably, is to think of a set of different usages to have a diversified offering, thus, enlarging the number of possible visitors.

The re-utilization of the villages of the Sicilian latifundium is technically possible and socially suitable. However, it is facilitated by certain measures under the regional funding programs that would enhance a major portion of the historical and cultural heritage of Sicily.

\section{References}

[1] A. Pennacchi, Fascio e martello: Viaggio nelle città del Duce (Fasces and Hammer: Travel in the Duce's Cities), Laterza, Bari, Italy, 2008. (in Italian)

[2] D. Ortensi, Edilizia rurale, urbanistica di centri comunali e borgate rurali (Rural Buildings, Town Planning of the Local Community and Rural Villages), Mediterranea, Rome, Italy, 1938. (in Italian)

[3] V. Sapienza, Autarchia e innovazione nella costruzione della città rurale dell'ECLS (Autarky and innovation in the construction of the Sicilian rural city), Agorà 44 (2013) 25-31. (in Italian)

[4] A. Maria, I borghi di Sicilia (The rural Sicilian villages), Architettura 5 (1941) 185-98. (in Italian)

[5] M. Finley, D. Mack Smith, C. Duggan, A History of Sicily, Chatto \& Windus, London, UK, 1986.

[6] F. Faro, Condizione rurale e pianificazione in Sicilia (Rural condition and urban planning in Sicily), Quaderno IDAU 14 (1984) 55-74. (in Italian)

[7] G. di Fazio, S. Contrafatto, Rural planning in Sicily between the two World Wars, in: Proceedings of the Fifth International Documentation and Conservation of the Modern Movement, Stockholm, 1998.

[8] L. Dufour, Nel Segno del Littorio, città e campagne siciliane nel ventennio (In Littorio's Sign, Cities and Countryside under the Duce in Sicily), Lussografica, Caltanissetta, Italy, 2005. (in Italian)

[9] V. Sapienza, La colonizzazione del latifondo siciliano, esiti e possibili sviluppi (The Colonization of the Sicilian Latifundium), Lussografica, Caltanissetta, Italy, 2011. (in Italian)

[10] S. Giedion, Space, Time and Architecture: The Growth of a New Tradition, Harvard University Press, Cambridge, UK, 1941.

[11] V. Sapienza, Borgo Cascino a Enna: una città dal Duce nel cuore del latifondo siciliano (Borgo Cascino of Enna: A Duce's town in the middle of the Sicilian latifundium), in: Proceedings of Paesaggio 150, Reggio Calabria, Italy, 2012. (in Italian) 